\title{
Skin rash from dengue fever
}

Tsuneaki Kenzaka, Ayako Kumabe

Division of General Medicine, Center for Community Medicine, Jichi Medical University School of Medicine, Shimotsuke, Tochigi, Japan

\section{Correspondence to}

Dr Tsuneaki Kenzaka, smile.kenzaka@jichi.ac.jp

\section{DESCRIPTION}

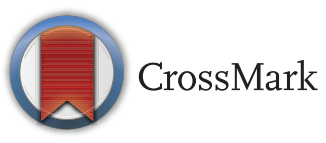

To cite: Kenzaka T, Kumabe A. BMJ Case Rep Published online: [please include Day Month Year] doi:10.1136/bcr-2013201598
A 47-year-old Japanese man presented with a history of having been bitten by mosquitoes, several years earlier in the Philippines, this resulted in a fever and a rash which dissipated spontaneously. He had stayed in the Philippines for 3 weeks, 1 month prior to hospitalisation, and was bitten by several mosquitoes. He had a fever for 6 days and a systemic rash for 3 days before consultation at our hospital. At the time of consultation, his blood pressure was $122 / 78 \mathrm{~mm} \mathrm{Hg}$; pulse $80 \mathrm{bpm}$, respiratory rate 16 breaths/min and body temperature $38.4^{\circ} \mathrm{C}$. Congestion of the palpebral conjunctiva and systemic rash were observed. A tourniquet test on the right arm showed increased petechial haemorrhaging (figure 1). Further, 'islands of white' of the normal skin surrounded by

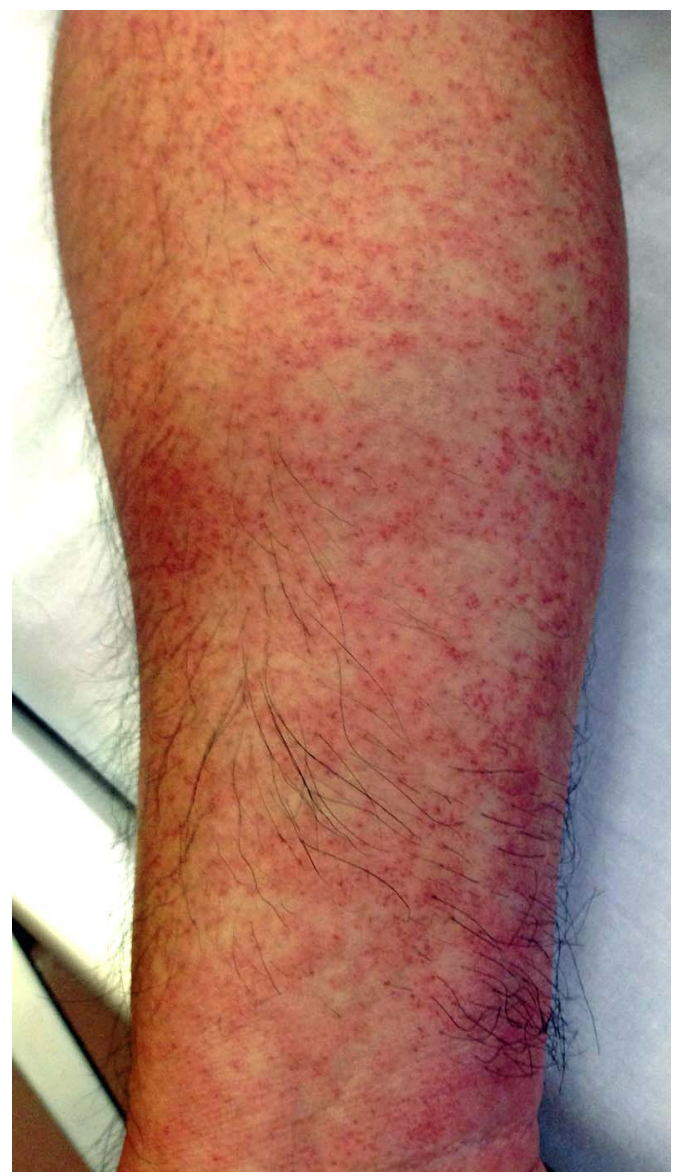

Figure 1 Tourniquet test positive: showing numerous minute petechial haemorrhages after tourniquet application. erythema were noted (figure 2). Blood tests showed the blood platelet count at $52 \times 10^{9}$ cells/L, with abnormal liver function. He received in-patient treatment for suspected dengue fever. A definitive diagnosis of dengue fever was obtained by assessing the levels of dengue virus IgM antibody that was 6.8 (positive cut-off, 1.1 or higher), IgG antibodies 3.5 (positive cut-off, 1.1 or higher) and dengue virus NS1 antigen 18.4 (positive cut-off, 1.0 or higher). A considerable amount of fluid replacement stopped the worsening of his condition and mitigated it, and within 1 week, he was discharged. Even in non-epidemic areas, the diagnosis should be considered in any patient presenting with a characteristic skin rash that has developed within 14 days after even a brief trip to the tropics or subtropics. ${ }^{1}$

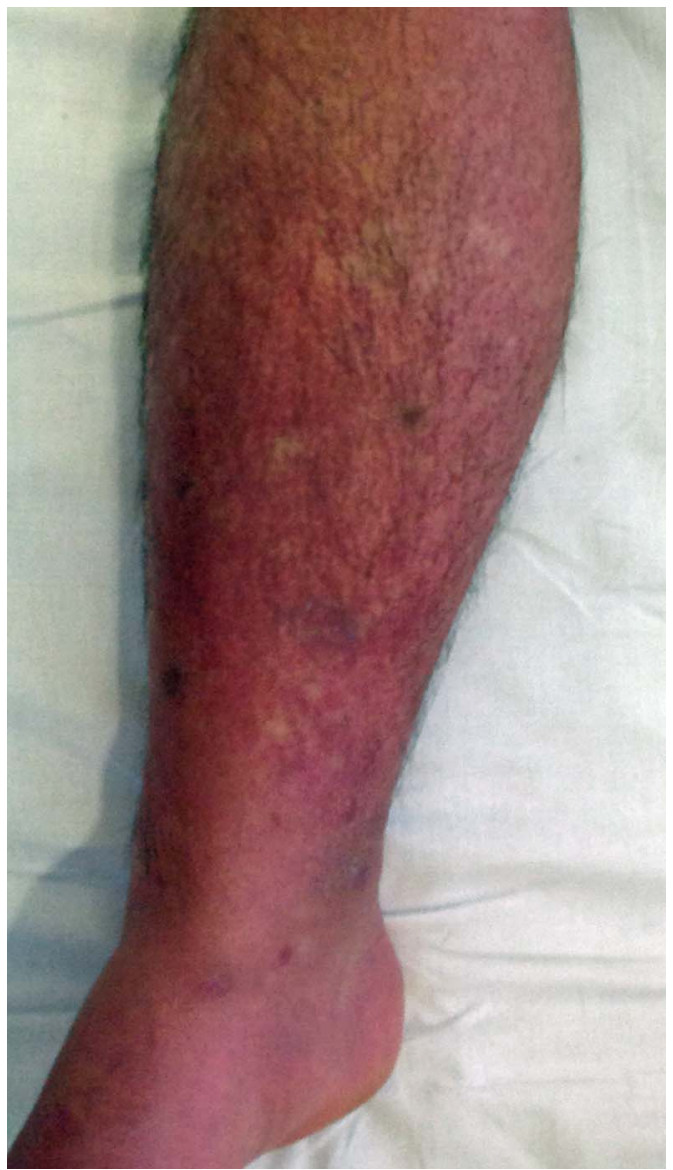

Figure 2 The 'islands of white' of the normal skin surrounded by erythema. 


\section{Learning points}

- Positive tourniquet test and 'islands of white in a sea of red' are characteristic skin rash in dengue fever.

- Even in non-epidemic areas, the diagnosis should be considered in any patient presenting with characteristic skin rash that has developed within 14 days after even a brief trip to the tropics or subtropics.
Competing interests None.

Patient consent Obtained.

Provenance and peer review Not commissioned; externally peer reviewed.

\section{REFERENCE}

1 Simmons CP, Farrar JJ, Nguyen VC, et al. Dengue. N Engl J Med 2012;366:1423-32.

Copyright 2013 BMJ Publishing Group. All rights reserved. For permission to reuse any of this content visit http://group.bmj.com/group/rights-licensing/permissions.

BMJ Case Report Fellows may re-use this article for personal use and teaching without any further permission.

Become a Fellow of BMJ Case Reports today and you can:

- Submit as many cases as you like

- Enjoy fast sympathetic peer review and rapid publication of accepted articles

- Access all the published articles

- Re-use any of the published material for personal use and teaching without further permission

For information on Institutional Fellowships contact consortiasales@bmjgroup.com

Visit casereports.bmj.com for more articles like this and to become a Fellow 